\title{
Short communication: Diets supplemented with starch and corn oil, marine algae, or hydrogenated palm oil differently affect selected metabolite concentrations in cow and goat milk
}

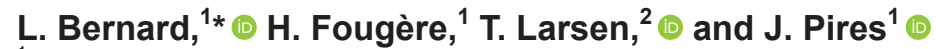 \\ ${ }^{1}$ Université Clermont Auvergne, INRAE, VetAgro Sup, UMR Herbivores, F-63122 Saint-Genès-Champanelle, France \\ ${ }^{2}$ Department of Animal Science, Aarhus University, DK-8830 Tiele, Denmark
}

\begin{abstract}
The objective was to investigate the effects of species (cow vs. goat) and of various dietary lipid supplements, known to modulate milk fat content, on selected metabolites and enzymes in milk and to explore their correlations with performance traits. Twelve Holstein cows and 12 Alpine goats, all multiparous and nonpregnant, and at $86 \pm 24.9$ and $61 \pm 1.8$ DIM, respectively, were fed a basal diet ( $45 \%$ forage $+55 \%$ concentrate) not supplemented (CTL) or supplemented with corn oil plus wheat starch [COS, $5 \%$ of diet dry matter (DM)], marine algae powder (MAP, $1.5 \%$ of diet DM), or hydrogenated palm oil (HPO, $3 \%$ of diet DM) in a replicated $4 \times 4$ Latin square design with 28 -d experimental periods. Intake, milk production and composition, milk fatty acid profile, and plasma metabolite concentrations were previously reported. Concentrations of 9 milk metabolites [ $\beta$-hydroxybutyrate (BHB), glucose, glucose-6-phosphate, isocitrate, choline, glutamate, urea, cholesterol, and free amino groups] and 2 milk enzyme activities (alkaline phosphatase and lactate dehydrogenase) were measured on d 24 of each experimental period. Dairy performance data showed marked species and diet effects on milk fat content. Irrespective of diet, cow milk was richer in alkaline phosphatase and glucose compared with goat milk (16 and 3 times more, respectively), whereas goat milk had greater urea and glucose-6-phosphate concentrations compared with cow milk (1.9 and 5.3 times more, respectively). In cows, COS decreased milk BHB and choline $(-25$ and $-43 \%$, respectively) compared with CTL, whereas no effects were observed in goats. The COS and MAP diets increased milk isocitrate compared with CTL in cows, but COS decreased isocitrate concentrations in goat milk. Milk choline was correlated with milk fat content in cows (Spearman $\left.\mathrm{r}, \mathrm{r}_{\mathrm{S}}=+0.73\right)$ and goats $\left(\mathrm{r}_{\mathrm{s}}=+0.58\right)$,
\end{abstract}

Received December 4, 2019.

Accepted January 29, 2020.

*Corresponding author: laurence.bernard@inrae.fr and lactate dehydrogenase activity was correlated with milk somatic cell count $\left(\mathrm{r}_{\mathrm{s}}=+0.66\right)$ in cows but not in goats. We provide evidence of different milk metabolite responses according to species and diets. Metabolites and enzymes secreted in milk may be indicators of specificities of lipid metabolism among ruminant species and may contribute to a better understanding of mechanisms regulating milk fat secretion. Changes in the concentrations of some metabolites considered minor components of milk may be valuable diagnostic tools of mammary gland and animal metabolism as well as of milk processing characteristics.

Key words: ruminant, lipid supplement, milk fat content, milk metabolite, milk enzyme

\section{Short Communication}

In dairy ruminants, among the multitude of milk components, some can be used to monitor performance traits (e.g., yield, fat and protein content and their ratios), whereas others are determinants of milk nutritional quality [e.g., fatty acids (FA), polar lipids, casein composition]. Minor components (vitamins, metabolites, free FA, miRNA, and others) may modulate nutritional or technological qualities of dairy products and may be indicators of animal physiology and metabolism. Among the husbandry factors, nutrition, particularly lipid supplementation, is a major lever to improve ruminant diet energy content and milk fat composition. Nonetheless, under certain conditions, diets rich in starch and PUFA from plants or diets supplemented with PUFA of marine origin may cause milk fat depression (MFD; Bauman and Griinari, 2001) in dairy cows but not, or to a lower extent, in goats (Toral et al., 2015). The addition of palm oil, rich in saturated FA, may increase milk fat content in both species (Mosley et al., 2007). Whatever the effects on milk fat content, the composition of major components of the milk fat fraction are modified by these diets, and the mechanisms underlying these milk traits remain poorly documented. To our knowledge, no data are available concerning the effects of lipid supplementation and 
MFD on minor milk metabolite concentrations. Milk metabolites may be derived primarily from the activity of the mammary epithelial cells (Larsen et al., 2010; Silanikove et al., 2014; Zachut et al., 2016). Although the biological processes modulating milk metabolite composition are not completely clear, they have been used to study the nutritional status of dairy cows and mammary gland function, using targeted approaches (Silanikove et al., 2014; Zachut et al., 2016; Billa et al., 2020) and metabolomics (Sundekilde et al., 2011; Klein et al., 2012; Tian et al., 2016; Xu et al., 2018). Milk lactate dehydrogenase and alkaline phosphatase activities were related to mammary infections (Larsen et al., 2010). Phosphocholine, choline, glycerophosphocholine, and $\beta$-hydroxybutyrate have been related to ketosis, energy balance (Klein et al., 2012; Silanikove et al., 2014; Xu et al., 2018), and heat stress (Tian et al., 2016) in dairy cows. Furthermore, milk isocitrate and glucose-6 phosphate, glucose, glutamate, and free amino groups are correlated with energy balance in feed-restricted mid-lactation cows (Billa et al., 2020). Therefore, a growing number of studies indicate that milk metabolite and enzyme concentrations may be used to assess metabolic and energy status of dairy cows and are promising markers for disease diagnosis.

The objective of this study was to evaluate milk metabolite and enzyme content in cows and goats receiving lipid supplements with contrasted effects on milk fat secretion. This research is part of a previously published experiment demonstrating strong species specificities regarding milk fat content and fatty acid composition in response to these diets (Fougère et al. 2018). We hypothesized that concentrations of selected minor constituents in milk would be modified during milk fat depression and that diet responses would be species dependent, providing further insights into the metabolic pathways involved in the regulation of milk fat secretion.

The Auvergne Rhône-Alpes Ethics Committee for Experiments on Animals approved all experimental procedures (France; DGRI's agreement APAFIS\#32772015121411432527v5), which were compliant with the guidelines established by the European Union Directive 2010/63/EU. The details of the experimental design are described in Fougère et al. (2018). Briefly, 12 Holstein cows and 12 Alpine goats, all multiparous and nonpregnant, and at $86 \pm 24.9$ and $61 \pm 1.8$ DIM, respectively, were allocated to 1 of 4 groups in each species ( 3 animals per group balanced according to DIM, milk production, milk fat, and milk protein content) and randomly assigned to treatments in a replicated $4 \times 4$ Latin square design with 28-d experimental periods. Treatments were ad libitum intake of diets composed of grass hay and concentrate containing either no additional lipid (control, CTL), corn oil and wheat starch (COS, 5.0\% of total DMI), marine algae powder of Schizochytrium sp. (MAP, $1.5 \%$ of total DMI), or hydrogenated palm oil (HPO, $3.0 \%$ of total DMI; Table 1). Diets were offered as 2 equal meals at 0830 and $1600 \mathrm{~h}$, starting with the concentrate distribution (containing the lipid supplements for COS, MAP, and HPO) and followed by hay. Concentrate and hay refusals were weighed daily and used to adjust the amounts of feed offered to maintain the targeted dietary forage-to-concentrate ratio (45:55 on a DM basis).

Feed intake, the chemical composition of experimental diets (Table 1), and milk yield were determined for each experimental period according to sampling protocols and analytical procedures described elsewhere (Fougère et al., 2018). Individual milk yields were recorded over 6 milkings on d 21, 22, and 24 of each of the 4 experimental periods. Simultaneously, milk samples were individually collected, treated with a preservative (bronopol-B2), and analyzed for fat, protein, and lactose content (Lial Massif Central, Aurillac, France). Additional milk samples were collected over 2 consecutive milkings starting at $0800 \mathrm{~h}$ on $\mathrm{d} 24$ of each experimental period and stored at $-20^{\circ} \mathrm{C}$ for $\mathrm{FA}$ analysis (Fougère et al., 2018). Selected metabolites and enzymes were measured in morning milk samples on d 24. Enzymatic fluorometric methods were used to quantify milk content of BHB (Larsen and Nielsen, 2005), uric acid (Larsen and Moyes, 2015), isocitrate (Larsen, 2014), glucose and glucose-6-phosphate (Larsen, 2015), glutamate and free amino groups (Larsen and Fernández, 2017), cholesterol (Larsen, 2012), choline (Klein et al., 2012), and lactate dehydrogenase (Larsen, 2005) and alkaline phosphatase activities (Larsen et al., 2010).

Statistical analyses were performed using the MIXED procedure of SAS (version 9.4; SAS Institute Inc., Cary, NC). Models included the fixed effects of period, species, experimental diet, the interaction of species and diet, and the random effect of individual animal nested within species. The differences between means were evaluated using the PDIFF option of the LSMEANS statement of SAS and the Tukey-Kramer adjustment for multiple comparisons. Spearman's correlation coefficients $\left(\mathbf{r}_{\mathrm{s}}\right)$ were generated for associations among milk metabolite concentrations, enzyme activities, production (milk yield and composition, energy and protein balance), and plasma metabolite concentrations. The significance level was predefined as $P<0.05$ and trends toward significance at $0.05 \leq P \leq 0.10$.

Treatment effects on animal performance and milk composition are reported in Table 2 and in Fougère et al. (2018). The DMI per kilogram of BW was $50 \%$ higher $(P<0.001)$ in goats than in cows, and the milk yield per kilogram of BW was higher $(P=0.002,+38 \%)$ 
Bernard et al.: SHORT COMMUNICATION: MILK METABOLITES IN COWS AND GOATS

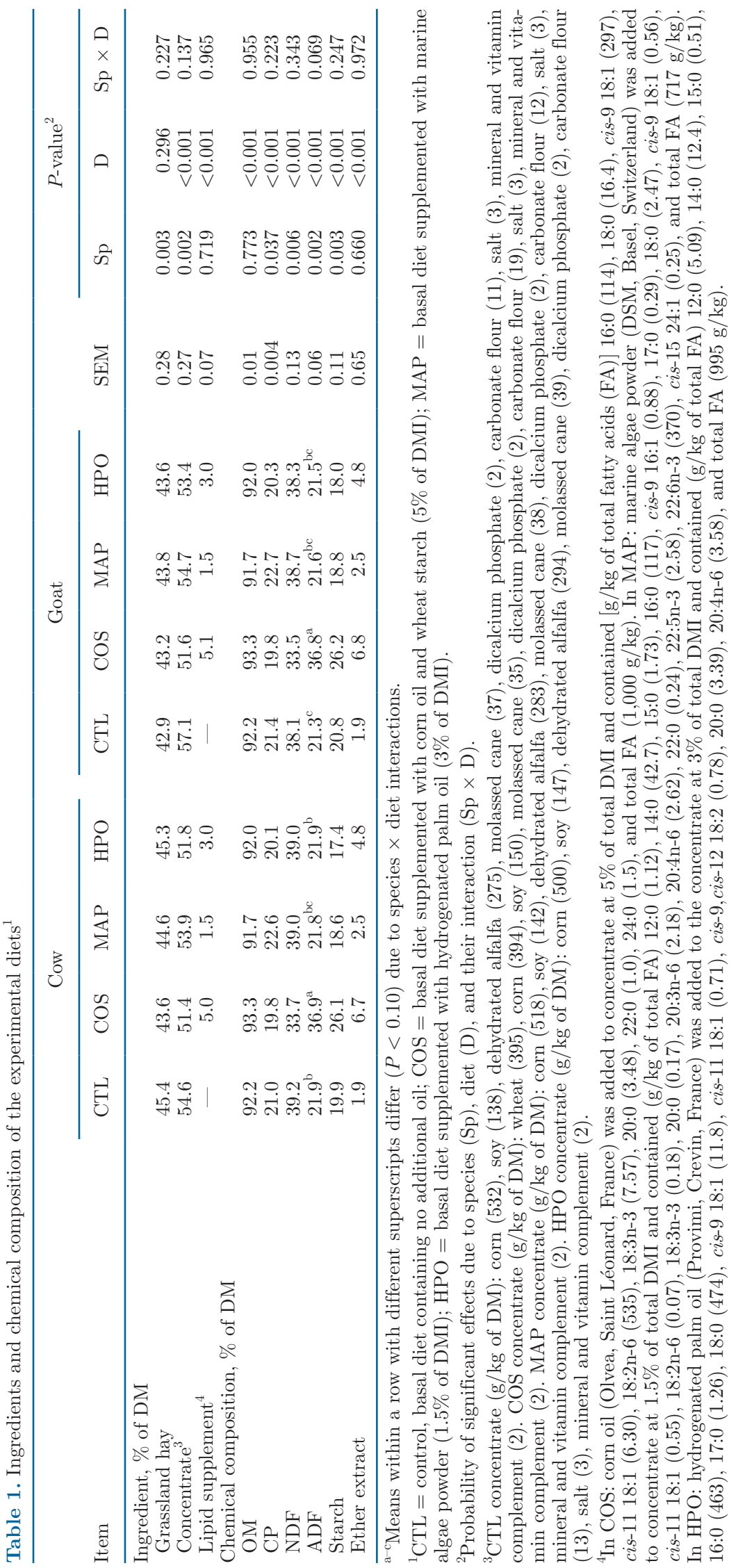


for goats than for cows (Table 2). Milk fat content did not differ between species when receiving CTL. Energy and protein balances were close to or above $100 \%$ in all treatments for both species (Table 2). Relative to CTL, only COS increased the energy balance $(24 \%)$ in cows, and only HPO in goats (17\%). Furthermore, in goats, COS decreased the protein balance by $17 \%$. The inclusion of oil supplements affected DMI (expressed per kilogram of BW; $P<0.001)$ similarly in both species (Table 2), with a decrease of $15 \%$ for COS compared with CTL. In cows, COS decreased the milk fat content by $45 \%$ compared with CTL (Table 2), and MAP decreased milk fat content by 22 and $15 \%$ in cows and goats, respectively. Moreover, HPO increased milk fat content in cows by $13 \%$. In cows, protein content increased with COS by $7 \%$, and lactose content decreased with MAP by $5 \%$ compared with CTL (Fougère et al., 2018).

Significant species effects were observed for most milk metabolites and enzymes studied (Table 3). Irrespective of the diet, cow milk was richer in alkaline phosphatase enzyme and glucose than that of goats (16 and 3 times more, respectively; $P<0.01$ ), whereas goat milk contained greater concentrations of urea and glucose-6-phosphate than that of cows (1.9 and 5.3 times more, respectively; $P<0.01$ ). This direct comparison of 9 milk metabolites and 2 milk enzymes in cows and goats fed similar diets provides clear evidence of differences of whole-animal and mammary tissue metabolism between ruminant species (Fougère and Bernard, 2019).

A trend for a species $\times$ diet interaction was observed for milk BHB. In cows, COS decreased BHB and choline $(-25$ and $-43 \%$, respectively; $P<0.001)$ compared with CTL, but not in goats. These effects are in line with the decrease in milk fat content observed when cows received COS. Milk choline was correlated with milk fat content $\left(\mathrm{r}_{\mathrm{s}}=+0.73, P<0.0001\right)$ in cows (Table 4), which accords with earlier studies (Erdman, 1992; Artegoitia et al., 2014) hypothesizing that choline supplementation may increase milk fat percentage, given the role of choline in lipid metabolism and phospholipid synthesis. This could be due to the lipotropic role of choline favoring the transport of triacylglycerols that provide fatty acids to the mammary gland (Pinotti et al., 2005). Furthermore, milk metabolomics research in early-lactating cows showed that choline was among the top 15 most relevant variables associated with energy balance (Xu et al., 2018). Moreover, various data support milk choline as a relevant indicator of animal metabolism (lipid metabolism, metabolic status) and of milk properties. It has been reported that choline is an important nutrient for early-lactation cow health (Pires and Grummer, 2008; Santos and Lima, 2009) and that it is related to milk coagulation properties (Sundekilde

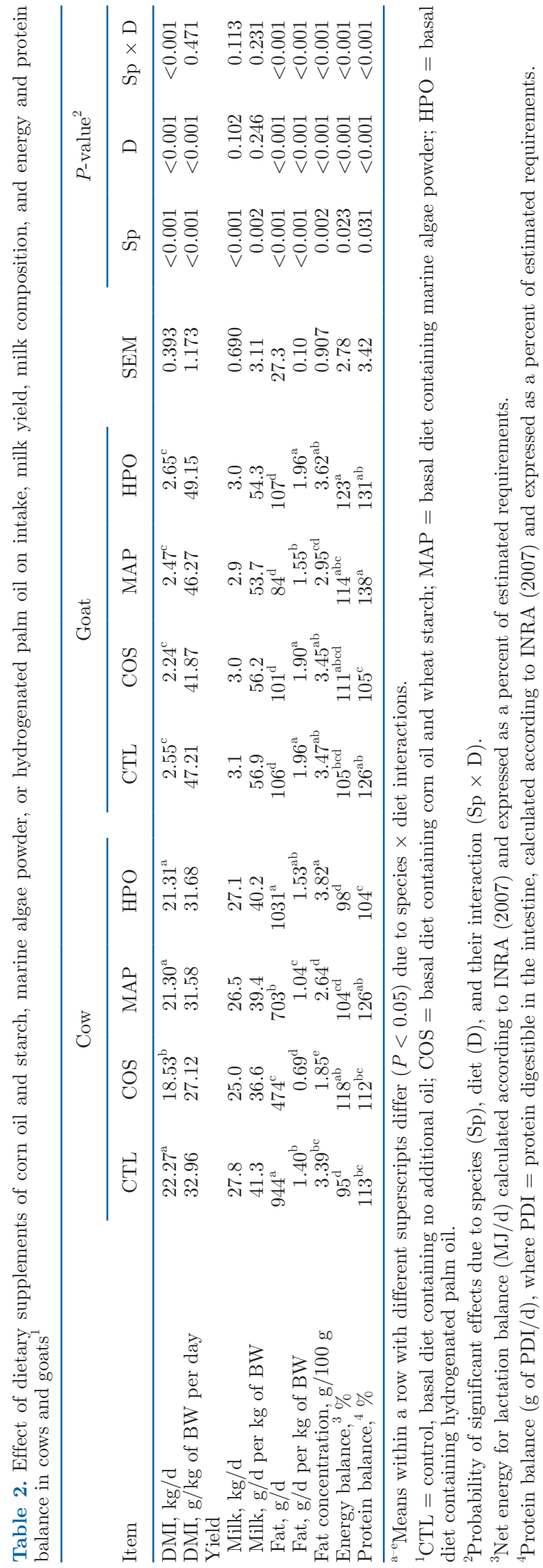




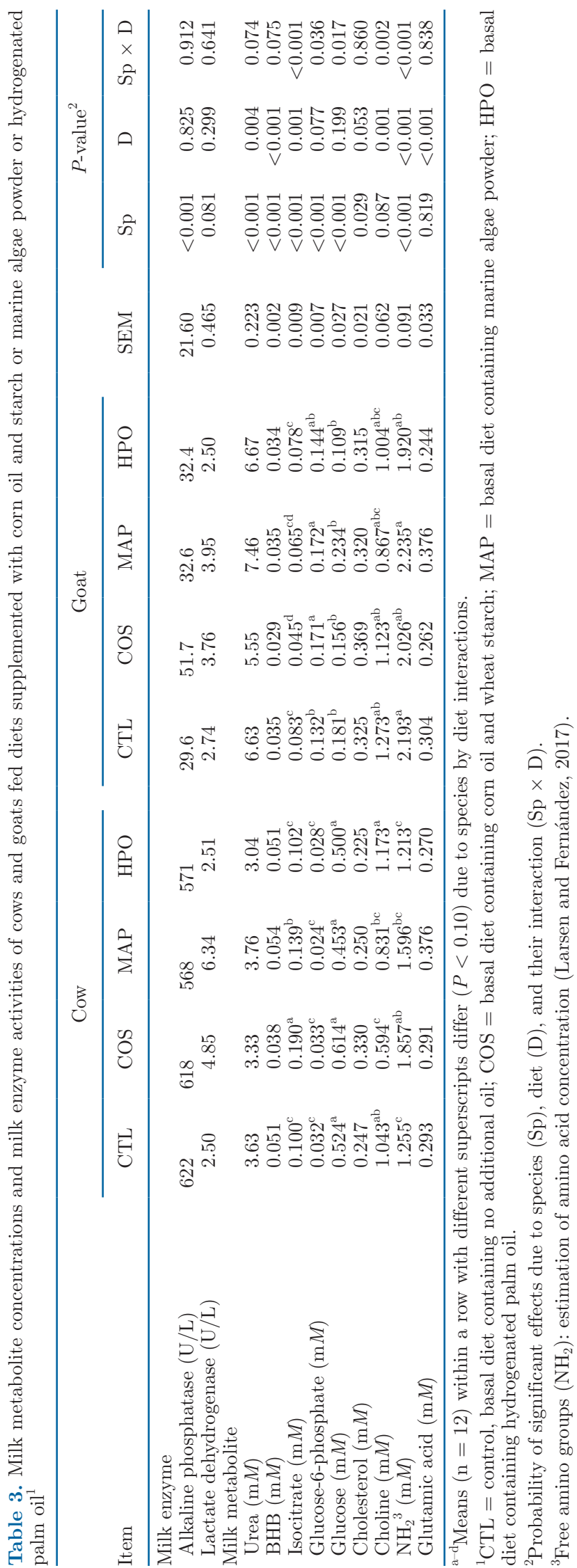

et al., 2011), and milk choline content may differentiate feeding systems (O'Callaghan et al., 2018).

Milk and plasma BHB were positively correlated in cows $\left(\mathrm{r}_{\mathrm{s}}=+0.63, P<0.001\right)$ and goats $\left(\mathrm{r}_{\mathrm{s}}=+0.63, P\right.$ $<0.001$ ), as observed in early-lactating cows (Nielsen et al., 2003; Oetzel and Cornell, 2012). In the present experiment, decreases in BHB content in plasma (Fougère et al., 2018) and milk were observed when cows received COS. These effects may reflect modifications of ruminal fermentation and VFA profile because plasma BHB is derived in part from rumen butyrate, which decreased in favor of propionate synthesis in cows under high-starch diets (Miettinen and Huhtanen, 1996). The decrease in milk BHB in cows under COS presented a trend for a species $\times$ diet interaction, which is in line with the differences in rumen fermentation characteristics (Miettinen and Huhtanen, 1996) and in the rumen microbiota of bovine and caprine ruminant species (Toral et al., 2016) under diets rich in starch and lipids.

The COS and MAP diets increased milk isocitrate content by 91 and 40\%, respectively, compared with CTL in cows, but COS decreased isocitrate concentrations in goats by $46 \%$. Isocitrate is a substrate for NADPH synthesis via the isocitrate dehydrogenase pathway. This pathway supplies the majority of the reducing equivalents, NADPH, used in fat synthesis in ruminants. Increased milk isocitrate could therefore reflect the lipid metabolism status of epithelial cells. Increased milk isocitrate content during MFD in cows may result from downregulation of isocitrate dehydrogenase activity in epithelial cells due to decreased de novo FA synthesis (Faulkner and Peaker, 1982). In contrast, milk isocitrate concentrations decreased in goats under COS, which did not present MFD nor decrease in de novo synthesized FA (Fougère et al., 2018). Previously, it was shown that a 6 -d partial feed restriction in mid-lactation cows induced transient increases in milk isocitrate and glucose-6P concentrations (Billa et al., 2020). In the present study, samples were collected $24 \mathrm{~d}$ after diet change; therefore, potential short-term modifications of milk metabolite concentrations could not be studied. In cows, COS increased total free amino groups by $48 \%$, which is an indicator of total free AA content. This increase in soluble AA and amines was coincident with higher levels of milk protein when cows were fed COS (Fougère et al., 2018). Moreover, free amino group concentrations were negatively correlated with milk fat content in cows $\left(\mathrm{r}_{\mathrm{s}}=-0.59, P<0.001\right.$; Table 4), which is probably a noncausal relationship. This result in cows receiving COS agrees with metabolomics research showing increased $\mathrm{AA}$ and amine content in the ruminal fluid of cows experiencing MFD (Zeng et al., 2019). Generally, cow milk contained a 


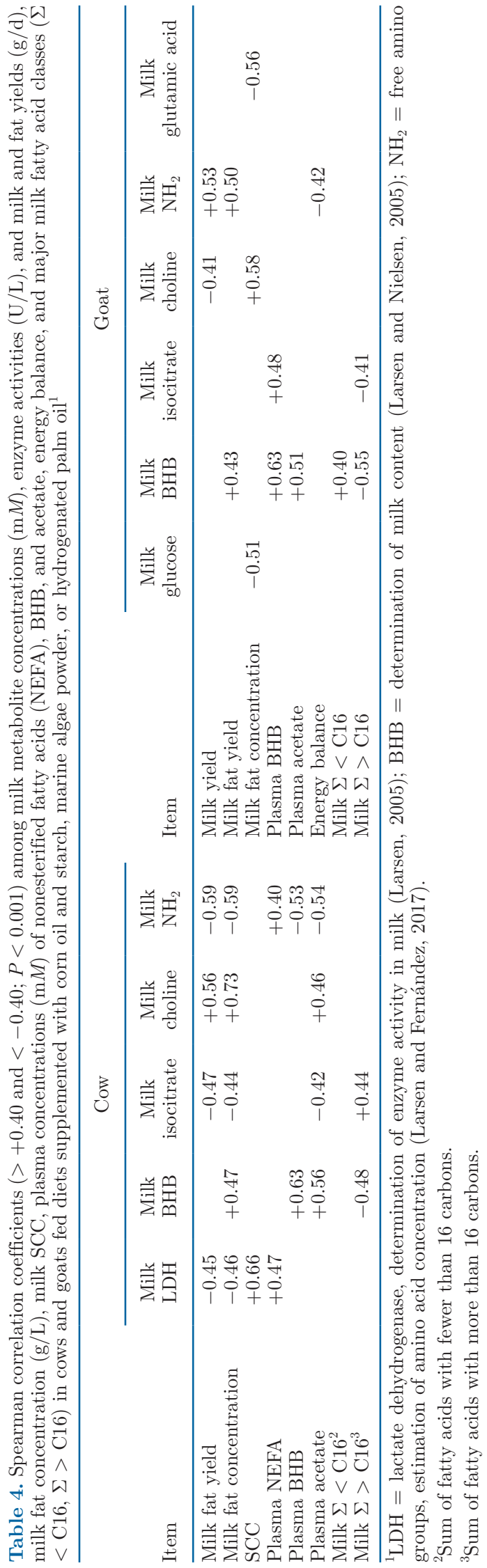

lower level of free amino groups than goat milk but a similar level of free glutamate. The fact that glutamate is a subset of the free amino content indicated that goat milk contains considerably higher concentrations of other sources of amines than glutamate. Milk lactate dehydrogenase, which has been proposed as an early indicator of mastitis in cows (Larsen et al., 2010), was correlated with $\mathrm{SCC}$ in cows $\left(\mathrm{r}_{\mathrm{s}}=+0.66, P<0.001\right.$; Table 4); this was not the case in goats. However, SCC in goat milk has been questioned as a relevant indicator of mastitis (Stuhr et al., 2013).

In conclusion, these results strongly support that concentrations of selected metabolites in milk are indicators of the specificities of lipid metabolism among these 2 ruminant species and contribute to a better understanding of mechanisms of milk fat secretion. Indeed, changes in the concentrations of milk metabolites such as choline and isocitrate may be valuable diagnostic tools for detection of mammary gland problems, animal metabolism, and indicators of milk technological properties. Further research should take into account several milk metabolites together and the stage of lactation, and should assess short- as well as long-term responses.

\section{ACKNOWLEDGMENTS}

The experimental trial was financed by APIS-GENE (Paris, France) as part of the NutriLip project, and the doctoral fellowship awarded to Hélène Fougère was funded by APIS-GENE and the Auvergne-Rhône Alpes region (Clermont-Ferrand, France). Analyses of milk metabolites and enzymes were funded by UMR 1213 Herbivores (INRAE, Saint-Genes-Champanelle, France). The authors gratefully acknowledge the staff of Unité Expérimentale Herbipôle de Theix (INRAE, Saint-Genès-Champanelle, France; https://doi.org/10 $.15454 / 1.5572318050509348 \mathrm{E} 12)$ for their diligent care of the experimental animals; Sylvie Bardou-Valette and Martine Tourret from UMR 1213 Herbivores (INRA) and Jens Clausen from Aarhus University (Tiele, Denmark) for their assistance with sample collection and laboratory analysis; and Anne de la Foye from UMR 1213 Herbivores (INRAE) for help with statistical analyses. The authors declare no conflicts of interest.

\section{REFERENCES}

Artegoitia, V. M., J. L. Middleton, F. M. Harte, S. R. Campagna, and M. J. de Veth. 2014. Choline and choline metabolite patterns and associations in blood and milk during lactation in dairy cows. PLoS One 9:e103412. https://doi.org/10.1371/journal.pone .0103412 .

Bauman, D. E., and J. M. Griinari. 2001. Regulation and nutritional manipulation of milk fat: Low-fat milk syndrome. Livest. Prod. Sci. 70:15-29. https://doi.org/10.1016/S0301-6226(01)00195-6. 
Billa, P. A., Y. Faulconnier, T. Larsen, C. Leroux, and J. A. A. Pires. 2020. Milk metabolites as noninvasive indicators of nutritional status of midlactation Holstein and Montbéliarde cows. J. Dairy Sci. 103:3133-3146. https://doi.org/10.3168/jds.2019-17466.

Erdman, R. A. 1992. Vitamins. Pages 297-308 in Large Dairy Herd Management. H. H. Van Horn and C. J. Wilcox, ed. American Dairy Science Association, Champaign, IL.

Faulkner, A., and M. Peaker. 1982. Reviews of the progress of dairy science: Secretion of citrate into milk. J. Dairy Res. 49:159-169. https://doi.org/10.1017/S002202990002224X.

Fougère, H., and L. Bernard. 2019. Effect of diets supplemented with starch and corn oil, marine algae, or hydrogenated palm oil on mammary lipogenic gene expression in cows and goats: A comparative study. J. Dairy Sci. 102:768-779. https://doi.org/10.3168/ jds.2018-15288.

Fougère, H., C. Delavaud, and L. Bernard. 2018. Diets supplemented with starch and corn oil, marine algae, or hydrogenated palm oil differentially modulate milk fat secretion and composition in cows and goats: A comparative study. J. Dairy Sci. 101:8429-8445. https://doi.org/10.3168/jds.2018-14483.

INRA. 2007. Alimentation des bovins, ovins et caprins. Pages 150-163 in Besoins des Animaux: Valeur des Aliments. Tables INRA 2007. Quae, C/O INRA, Versailles, France.

Klein, M. S., N. Buttchereit, S. P. Miemczyk, A. K. Immervoll, C. Louis, S. Wiedemann, W. Junge, G. Thaller, P. J. Oefner, and W. Gronwald. 2012. NMR metabolomic analysis of dairy cows reveals milk glycerophosphocholine to phosphocholine ratio as prognostic biomarker for risk of ketosis. J. Proteome Res. 11:1373-1381. https://doi.org/10.1021/pr201017n.

Larsen, T. 2005. Determination of lactate dehydrogenase (LDH) activity in milk by a fluorometric assay. J. Dairy Res. 72:209-216. https://doi.org/10.1017/S0022029905000865.

Larsen, T. 2012. Enzymatic-fluorometric quantification of cholesterol in bovine milk. Food Chem. 135:1261-1267. https://doi.org/10 .1016/j.foodchem.2012.05.061.

Larsen, T. 2014. Fluorometric determination of free and total isocitrate in bovine milk. J. Dairy Sci. 97:7498-7504. https://doi.org/ 10.3168/jds.2014-8018.

Larsen, T. 2015. Fluorometric determination of free glucose and glucose 6-phosphate in cows' milk and other opaque matrices. Food Chem. 166:283-286. https://doi.org/10.1016/j.foodchem.2014.06 .017 .

Larsen, T., and C. Fernández. 2017. Enzymatic-fluorometric analyses for glutamine, glutamate and free amino groups in protein-free plasma and milk. J. Dairy Res. 84:32-35. https://doi.org/10.1017/ S0022029916000789.

Larsen, T., and K. M. Moyes. 2015. Are free glucose and glucose-6-phosphate in milk indicators of specific physiological states in the cow? Animal 9:86-93. https://doi.org/10.1017/S1751731114002043.

Larsen, T., and I. Nielsen. 2005. Fluorometric determination of $\beta$-hydroxybutyrate in milk and blood plasma. J. Dairy Sci. 88:2004-2009. https://doi.org/10.3168/jds.S0022-0302(05)72876 -9 .

Larsen, T., C. M. Rontved, K. L. Ingvartsen, L. Vels, and M. Bjerring. 2010. Enzyme activity and acute phase proteins in milk utilized as indicators of acute clinical E. coli LPS-induced mastitis. Animal 4:1672-1679. https://doi.org/10.1017/S1751731110000947.

Miettinen, H., and P. Huhtanen. 1996. Effects of the ratio of ruminal propionate to butyrate on milk yield and blood metabolites in dairy cows. J. Dairy Sci. 79:851-861. https://doi.org/10.3168/jds .S0022-0302(96)76434-2.

Mosley, S. A., E. E. Mosley, B. Hatch, J. I. Szasz, A. Corato, N. Zacharias, D. Howes, and M. A. McGuire. 2007. Effect of varying levels of fatty acids from palm oil on feed intake and milk production in Holstein cows. J. Dairy Sci. 90:987-993. https://doi.org/10.3168/ jds.S0022-0302(07)71583-7.

Nielsen, N. I., K. L. Ingvartsen, and T. Larsen. 2003. Diurnal variation and the effect of feed restriction on plasma and milk metabolites in TMR-fed dairy cows. J. Vet. Med. A Physiol. Pathol. Clin. Med. 50:88-97. https://doi.org/10.1046/j.1439-0442.2003.00496.x.
O'Callaghan, T. F., R. Vazquez-Fresno, A. Serra-Cayuela, E. Dong, R. Mandal, D. Hennessy, S. McAuliffe, P. Dillon, D. Wishart, C. Stanton, and R. Ross. 2018. Pasture feeding changes the bovine rumen and milk metabolome. Metabolites 8:27. https://doi.org/10 $.3390 /$ metabo8020027.

Oetzel, G. R., and U. Cornell. 2012. Understanding the impact of subclinical ketosis. Proc. 2012 Cornell Nutrition Conference for Feed Manufacturers. Cornell University Department of Animal Science, Ithaca, NY.

Pinotti, L., A. Campagnoli, V. Dell'Orto, and A. Baldi. 2005. Choline: Is there a need in the lactating dairy cow? Livest. Prod. Sci. 98:149-152. https://doi.org/10.1016/j.livprodsci.2005.10.013.

Pires, J., and R. R. Grummer. 2008. Micronutrients and their impact on high-performing dairy cows - A focus on niacin and choline. In Proc. Southwest Nutrition and Management Conference, Department of Animal Sciences, University of Arizona, Tucson, AZ.

Santos, J. E. P., and F. S. Lima. 2009. Feeding rumen-protected choline to transition dairy cows. Pages 149-159 in Proc. 20th Ann. Florida Ruminant Nutr. Symp. University of Florida, Gainesville, FL.

Silanikove, N., U. Merin, F. Shapiro, and G. Leitner. 2014. Milk metabolites as indicators of mammary gland functions and milk quality. J. Dairy Res. 81:358-363. https://doi.org/10.1017/ S0022029914000260.

Stuhr, T., K. Aulrich, K. Barth, K. Knappstein, and T. Larsen. 2013. Influence of udder infection status on milk enzyme activities and somatic cell count throughout early lactation in goats. Small Rumin. Res. 111:139-146. https://doi.org/10.1016/j.smallrumres .2012.09.004.

Sundekilde, U. K., P. D. Frederiksen, M. R. Clausen, L. B. Larsen, and H. C. Bertram. 2011. Relationship between the metabolite profile and technological properties of bovine milk from two dairy breeds elucidated by NMR-based metabolomics. J. Agric. Food Chem. 59:7360-7367. https://doi.org/10.1021/jf202057x.

Tian, H., N. Zheng, W. Wang, J. Cheng, S. Li, Y. Zhang, and J. Wang. 2016. Integrated metabolomics study of the milk of heat-stressed lactating dairy cows. Sci. Rep. 6:24208. https://doi.org/10.1038/ srep24208.

Toral, P. G., L. Bernard, A. Belenguer, J. Rouel, G. Hervás, Y. Chilliard, and P. Frutos. 2016. Comparison of ruminal lipid metabolism in dairy cows and goats fed diets supplemented with starch, plant oil, or fish oil. J. Dairy Sci. 99:301-316. https://doi.org/10.3168/ jds.2015-10292.

Toral, P. G., Y. Chilliard, J. Rouel, H. Leskinen, K. J. Shingfield, and L. Bernard. 2015. Comparison of the nutritional regulation of milk fat secretion and composition in cows and goats. J. Dairy Sci. 98:7277-7297. https://doi.org/10.3168/jds.2015-9649.

Xu, W., J. Vervoort, E. Saccenti, R. van Hoeij, B. Kemp, and A. van Knegsel. 2018. Milk metabolomics data reveal the energy balance of individual dairy cows in early lactation. Sci. Rep. 8:15828. https: //doi.org/10.1038/s41598-018-34190-4.

Zachut, M., G. Kra, Y. Portnik, F. Shapiro, and N. Silanikove. 2016. Milk glucose-6-phosphate dehydrogenase activity and glucose6-phosphate are associated with oxidative stress and serve as indicators of energy balance in dairy cows. RSC Adv. 6:65412-65417. https://doi.org/10.1039/C6RA11924G.

Zeng, H., C. Guo, D. Sun, H. Seddik, and S. Mao. 2019. The ruminal microbiome and metabolome alterations associated with diet-induced milk fat depression in dairy cows. Metabolites 9:154. https: //doi.org/10.3390/metabo9070154.

\section{ORCIDS}

L. Bernard (๑ https://orcid.org/0000-0003-1529-4243

T. Larsen (ํ https://orcid.org/0000-0003-3058-5938

J. Pires @ https://orcid.org/0000-0002-3773-9293 